\title{
Coral reefs next to a major conurbation: a study of temporal change (1985-2011) in coral cover and composition in the reefs of Jakarta, Indonesia
}

\author{
Daniel F. R. Cleary ${ }^{1}$, Ana R. M. Polónia ${ }^{1}$, Willem Renema ${ }^{2}$, Bert W. Hoeksema ${ }^{2}$, \\ Jackie Wolstenholme ${ }^{3}$, Yosephine Tuti ${ }^{4}$, Nicole J. de Voogd ${ }^{2, *}$ \\ ${ }^{1}$ Departamento de Biologia, CESAM - Centro de Estudos do Ambiente e do Mar, Universidade de Aveiro, $3810-193$ Aveiro, \\ Portugal \\ ${ }^{2}$ Naturalis Biodiversity Center, PO Box 9517, 2300 RA Leiden, The Netherlands \\ ${ }^{3}$ James Cook University, Townsville, Queensland 4811, Australia \\ ${ }^{4}$ Research Centre for Oceanography - Indonesian Institute of Sciences (LIPI), Jalan Pasir Putih I, Ancol Timur, Jakarta 11048, \\ Indonesia
}

\begin{abstract}
Coral reefs are diverse, ecologically important and globally threatened ecosystems. Numerous studies have reported on the threats to coral reefs, which include both local perturbations, such as pollution and overfishing, and widespread phenomena, such as bleaching. Here, we report on the history of the Jakarta Bay-Thousand Islands reef system from 1985 to 2011. Over this period, we recorded significant shifts in coral generic composition and an overall decline in coral cover with widely different trajectories between in-, mid- and offshore zones. In 1985, coral cover exhibited a clear on-to-offshore gradient with low coral cover inshore (10\%), moderate cover midshore $(49 \%)$ and high cover offshore $(74 \%)$. The low coral cover inshore contrasts strongly with reports of high coral cover for inshore reefs in 1929. Inshore, coral cover declined from $10 \%$ in 1985 to $<5 \%$ in 1995. The greatest change in coral cover and composition, however, occurred in offshore reefs, where mean cover declined from 74 to $<20 \%$ between 1985 and 1995. Acropora species were particularly affected and declined from 36 to just $5 \%$ cover offshore. Recovery of coral cover occurred offshore between 1995 and 2005. From 2005 to 2011, however, a less severe loss in coral cover was observed. With the exception of inshore reefs, which appear to be on an ongoing trajectory of decline that started before the 1985 surveys, the reefs of the Jakarta Bay-Thousand Islands system have shown a propensity to recover.
\end{abstract}

KEY WORDS: Coral cover · Disturbance $\cdot$ Java $\cdot$ Life form $\cdot$ Long-term study

\section{INTRODUCTION}

Coastal marine ecosystems are of global importance for climate, nutrient cycling and primary productivity (Solan et al. 2004). They are, however, under severe pressure from local anthropogenic disturbances, with more than two-thirds of the world's population living within $75 \mathrm{~km}$ of the coastline (Kuijper 2003). Human-induced disturbances, such as overfishing and pollution, have been taking

${ }^{*}$ Corresponding author: nicole.devoogd@naturalis.nl an increasing toll on these ecosystems (Solan et al. 2004). Coral reefs in particular have suffered massive, long-term declines in coral cover and dramatic shifts in community composition (Jackson et al. 2001, Pandolfi et al. 2003, Bruno \& Selig 2007, De'ath et al. 2012). In addition to local disturbances, such as pollution and overfishing, global disturbances, such as mass bleaching events, have had a detrimental impact on coral reefs (Carpenter et al. 2008). Importantly, large-scale disturbances related to global

(C) The authors 2014. Open Access under Creative Commons by Attribution Licence. Use, distribution and reproduction are unrestricted. Authors and original publication must be credited. 


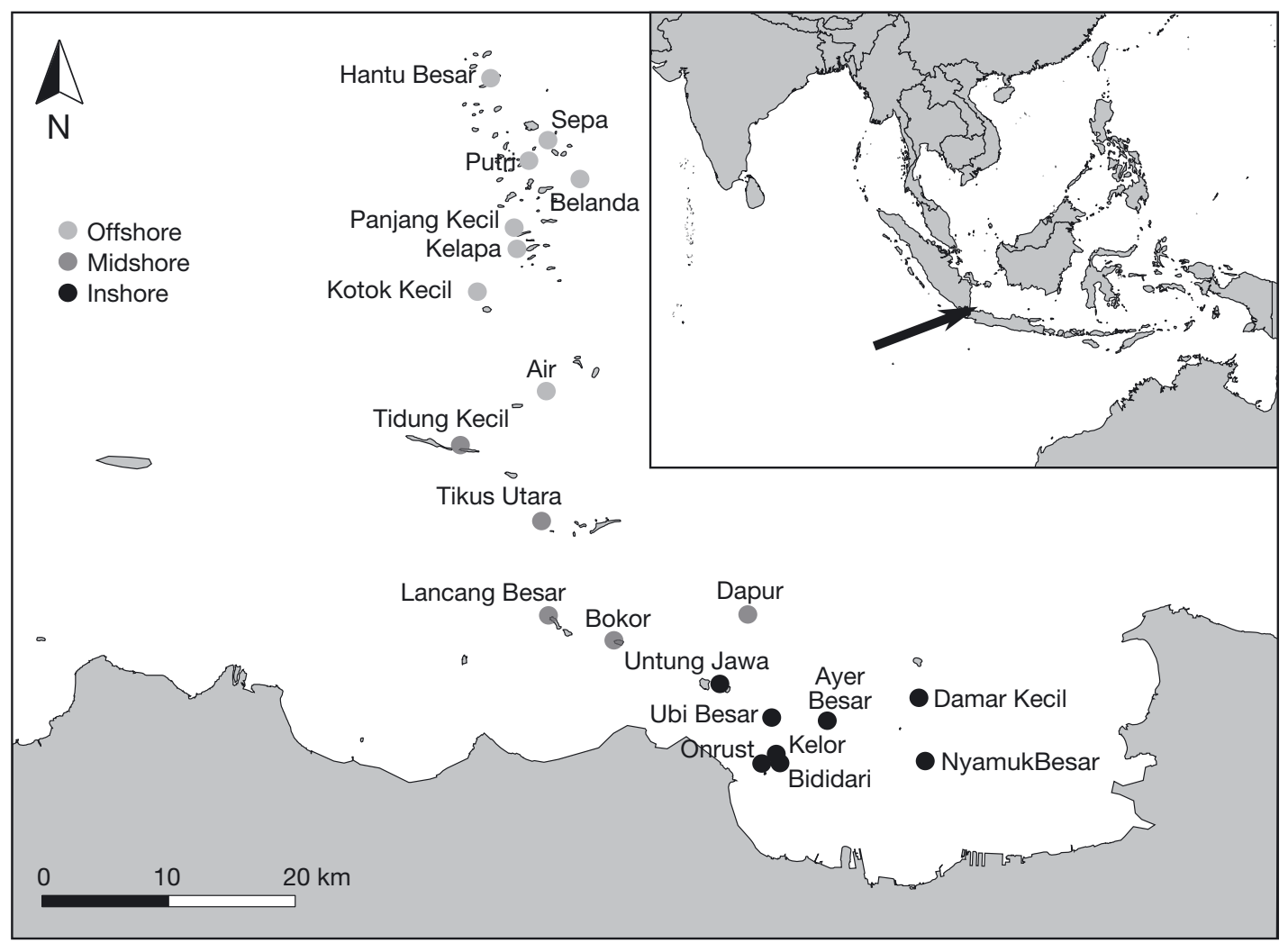

Fig. 1. Study area showing the location of study sites sampled from 1985 to 2011. Symbols represent inshore (black: to the south of $-5.97^{\circ}$ latitude), midshore (grey: between $-5.77^{\circ}$ and $-5.97^{\circ}$ latitude) and offshore (light grey: to the north of $-5.77^{\circ}$ latitude) sites. Inset shows the location of the study site on the island of Java

climate change are expected to increase in intensity over the coming decades (Done et al. 2010, Hughes et al. 2010). The interaction between local and global factors makes it imperative that a long-term approach be undertaken to understand how coral reefs have been affected over time. Very few data series spanning several decades are, however, available (Done et al. 2007). At present, long-term Indo-Pacific time series are generally restricted to the Great Barrier Reef (Connell 1997, Done et al. 2007, Sweatman et al. 2011, De'ath et al. 2012).

Here, we focus on reefs proximate to the conurbation of Greater Jakarta, Indonesia. This conurbation covers a total area of $2784 \mathrm{~km}^{2}$, and with $>26$ million inhabitants, it is the second most populous metropolitan area in the world after Tokyo (Demographia 2013). At present, it is by far the largest major agglomeration located adjacent to a coral reef complex. In recent decades, various forms of disturbance, including river discharge, urban development, tourism, destructive fisheries and coral mining have seriously affected these reefs (DeVantier et al. 1998, RachelloDolmen \& Cleary 2007, Cleary et al. 2008, Hosono et al. 2011). The main goal of the present study was to assess changes in coral generic composition and the cover of corals and other life forms (e.g. algae) in 3 zones (in-, mid- and offshore) over a 26 yr period, from 1985 to 2011.

\section{MATERIALS AND METHODS}

\section{Study site}

All sampling took place in the Jakarta Bay-Thousand Islands reef complex (hereafter referred to as JBTI), which extends from Jakarta Bay to $>80 \mathrm{~km}$ to the northwest in the Java Sea (Fig. 1). Several rivers transport sewage and storm water over a $2000 \mathrm{~km}^{2}$ catchment area to the central sector of the bay, defined by 2 flanking delta systems, both of which have a large sediment input (Rees et al. 1999). Annual precipitation averages $1700 \mathrm{~mm} \mathrm{yr}^{-1}$ with a 'wet' season during the northwest monsoon (November to March) and a 'dry' season during the southeast monsoon (May to September) (Rees et al. 1999). In the present study, we assessed a number of sites that were sampled in 1985, 1995, 2005 and 2011. 


\section{Sampling}

A detailed description of the sampling for 1985 is given in Cleary et al. (2006) and for 1995 in Cleary et al. (2008). Both studies noted highly significant differences in coral cover and composition among zones (in-, mid- and offshore); the inshore zone closest to the city of Jakarta was in particularly bad shape with very low coral cover. Sampling in 2005 took place from September 7 to 23 and sampling in 2011 took place from July 26 to August 9 following methods previously described in Cleary et al. $(2006,2008)$. Briefly, this entailed estimating the cover of coral colonies and other benthic cover categories (algae, dead coral, coral rubble and sand) using the line intercept transect survey method (English et al. 1997). This was achieved by measuring the intercept distance of individual live coral colonies and other benthic cover categories in shallow-water $(<5 \mathrm{~m}) 30 \mathrm{~m}$ transects. For the present study, we used data from 21 sample sites that have been consistently monitored. At each site, between one and twelve $30 \mathrm{~m}$ transects were surveyed (Table A1 in the Appendix). The number of transects sampled varied with the number of people available to measure and identify specimens during sampling events. No permanent transects were established, and new transects were set out during each sampling event. Benthic cover categories other than corals were only sampled from 1995 onwards. Note that for benthic cover, the percentage cover could exceed $100 \%$. In 1985, coral cover, for example exceeded $100 \%$ in some offshore transects because of coral overgrowth. Dead corals were also often covered by other benthic cover categories, particularly algae; estimates of dead coral thus include 'bare' dead coral and dead coral covered by algae. In addition to sampling benthic cover, water transparency was also measured once at each site during each sampling event using a Secchi disk.

Consistent with previous studies of the area (DeVantier et al. 1998, Cleary et al. 2006, 2008), all sample sites fell within specific zones along an on-tooffshore gradient. These included an inshore zone (Zone 1) to the south of $-5.97^{\circ}$ latitude, a midshore zone (Zone 2) between $-5.77^{\circ}$ and $-5.97^{\circ}$ latitude, and an offshore zone (Zone 3 ) to the north of $-5.77^{\circ}$ latitude (Fig. 1). The offshore zone is largely contained within the Pulau Seribu National Marine Park, the first marine park established in Indonesia (Farhan \& Lim 2012). Inshore sites were sampled in 1985, 1995 and 2005, while mid- and offshore sites were sampled in 1985, 1995, 2005 and 2011. Individual coral colonies were identified to species level when possible. Because different researchers conducted the line transect surveys throughout the time period investigated, we pooled observations to genera and growth form (Done et al. 2010) to avoid any potential among-observer bias.

\section{Analyses}

A data table containing the generic identity, abundance, colony intercept (length of transect covering a coral colony and an estimate of coral size), and cover of corals and other benthic cover categories per transect was imported into R (R Core Team 2013). After import, mean values of abundance, size (colony intercept) and cover were obtained for each of the 21 sample sites. We tested for significant deviations from normality and homogeneity of variance in total coral abundance and size using the shapiro.test and bartlett.test functions in R. Both tests revealed significant deviations from normality ( $p<0.05)$; we therefore used permutational ANOVAs with the adonis function in R using a Euclidean distance matrix to compare abundance and size among sampling events. Separate tests were run for each zone.

We tested for significant variation in the cover of coral morphologies (branching, encrusting, foliose, massive, submassive), other benthic cover categories (total coral cover, dead coral, soft coral, algae, rubble and sand) and the for the presence of most abundant coral genera (Acropora, Porites, Montipora, Seriatopora, Echinopora, Oulastrea and Pavona) among sampling events using an analysis of deviance with the $g \operatorname{lm}()$ function in R. Because the data were proportional, we first applied a glm with the family= argument set to binomial. The ratio, however, of residual deviance to residual $\mathrm{df}$ in the models substantially exceeded 1 , so we set family= to 'quasibinomial'. In the 'quasibinomial' family, the dispersion parameter is not fixed at 1 so that it can model overdispersion. Using the glm model, we tested for significant variation in life form cover among sampling events within each zone separately using the anova() function in $\mathrm{R}$ with the F-test, which is most appropriate when dispersion is estimated by moments, as is the case with quasibinomial fits.

\section{RESULTS}

A total of 443 transects were sampled across 3 zones (in-, mid- and offshore) from 1985 to 2011, representing a total distance of $13290 \mathrm{~m} ; 27439$ coral 
colonies were measured along these transects. There were highly significant differences in coral cover $\left(F_{3,28}=7.21, \mathrm{p}<0.001\right)$ and abundance $\left(F_{3,28}=8.16\right.$, $\left.\mathrm{p}<0.001, \mathrm{R}^{2}=0.467\right)$ among sampling events offshore but not in- or midshore. There were no significant differences in size among sampling events (Fig. 2). The Secchi disk data largely corroborated those of coral cover. In 1985, water transparency was highest offshore (>15 m) and lowest inshore $(6.4 \mathrm{~m})$. Transparency dropped in mid- and offshore zones from 1985 to 1995 with the greatest drop offshore (9.4 to $7.0 \mathrm{~m}$ midshore and 15.8 to $8.4 \mathrm{~m}$ offshore). Water transparency improved mid- and offshore from 1995 to 2011. Inshore, there was no substantial change in water transparency from 1985 to 1995 but a decline from a mean of $6.4 \mathrm{~m}$ in 1995 to only $3.4 \mathrm{~m}$ in 2005 .

In all 3 reef zones, there were marked changes over time in the cover of coral and other benthic cover categories. Inshore, mean coral cover was already very low $(<10 \%)$ in 1985 (Figs. 2 \& 3). Inshore reefs largely consisted of sand, algae and rubble in 1995 and 2005 (Fig. 4). Within the inshore zone, statistically significant changes included: (1) the virtual disappearance of Acropora $\left(F_{2,21}=16.21, \mathrm{p}<0.001\right)$ and (2) non-Acropora branching corals $\left(F_{2,21}=8.62\right.$, $\mathrm{p}=0.002$ ) from 1985 to 2005 (Fig. 3) and (3) a reduc- a) Cover inshore

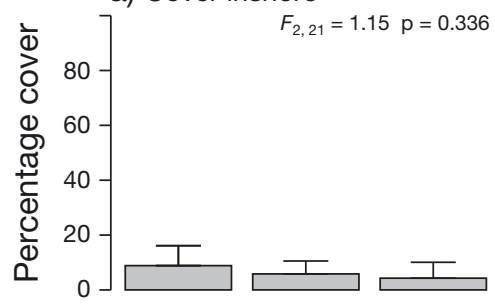

d) Abundance inshore

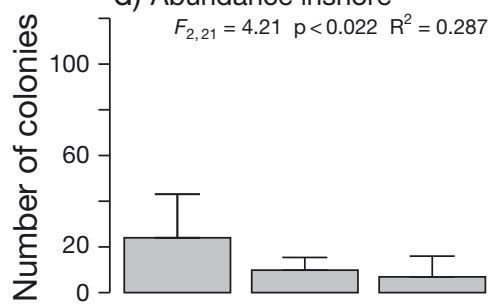

g) Size inshore
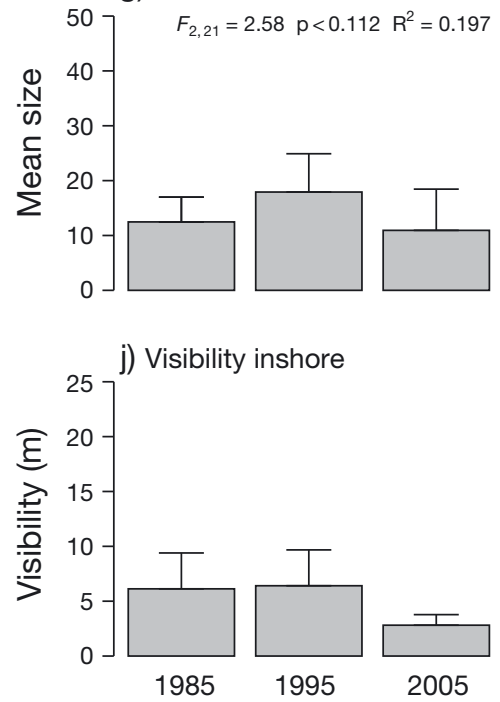

b) Cover midshore

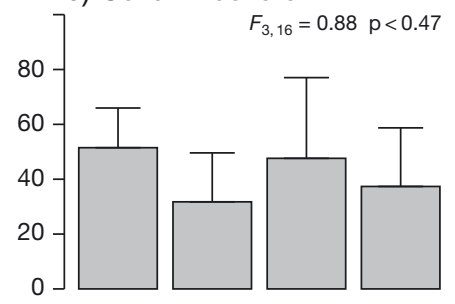

e) Abundance midshore

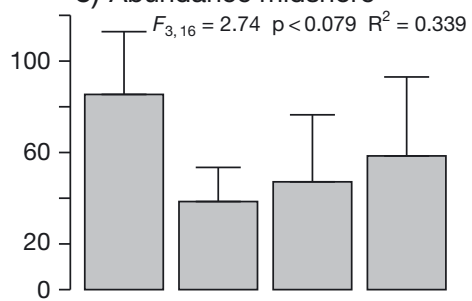

h) Size midshore
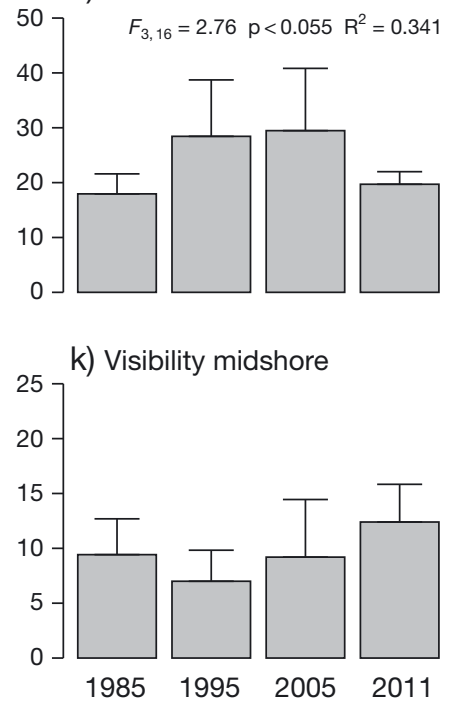

c) Cover offshore

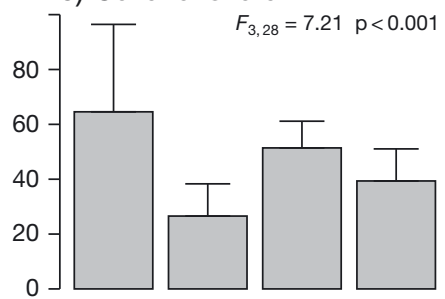

f) Abundance offshore
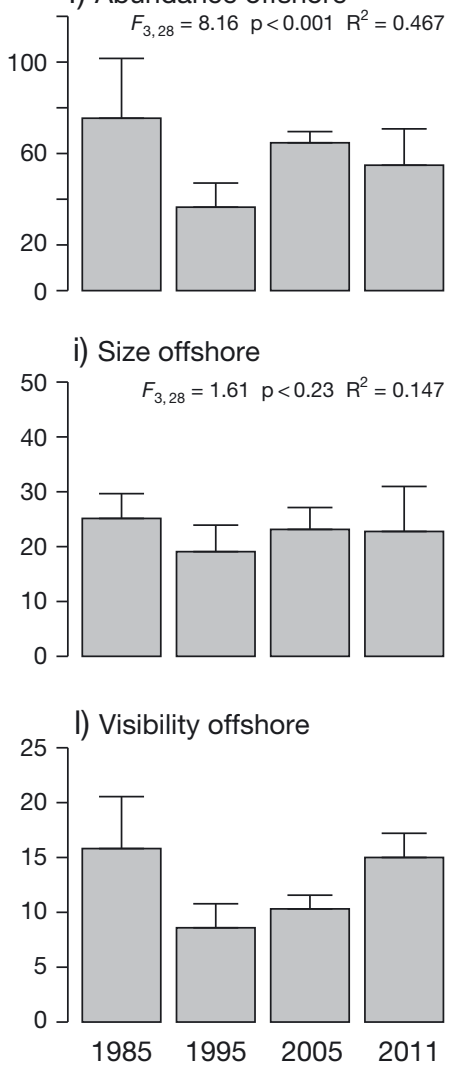

Fig. 2. Mean total coral cover in (a) inshore, (b) midshore and (c) offshore reefs. Mean abundance of colonies in (d) inshore, (e) midshore and (f) offshore reefs. Mean transect intercept (a proxy of size) of colonies in (g) inshore, (h) midshore and (i) offshore reefs. Mean visibility (water transparency measured using a Secchi disk) in (j) inshore, (k) midshore and (l) offshore reefs. Results of statistical analyses are given in each panel. Error bars are $+1 \mathrm{SD}$ 
tion in dead coral from 1995 to $2005\left(F_{1,14}=21.18, \mathrm{p}<\right.$ 0.001) (Fig. 4).

Midshore, total coral cover declined from almost $50 \%$ in 1985 to just over $30 \%$ in 1995 , but there was pronounced variation in cover among sites (Fig. 2). For example, coral cover in reefs of the island Bokor, which is the most nearshore of the midshore sites, declined from $37.3 \%$ in 1985 to $23.1 \%$ in 1995 , $9.9 \%$ in 2005 and only $3.5 \%$ in 2011 . Other midshore sites, however, maintained relatively high coral cover, e.g. Dapur at $43 \%$ and Tikus Utara at $63 \%$ in 2011. Statistically significant changes in the midshore zone included: (1) an increase in encrusting corals $\left(F_{3,16}=\right.$
9.06, $\mathrm{p}<0.001) ;(2)$ a reduction in submassive corals $\left(F_{3,16}=12.87, \mathrm{p}<0.001\right)$ (Fig. 3); (3) a drop in dead coral cover from 1995 to 2005 followed by an increase in $2011\left(F_{2,12}=6.33, \mathrm{p}=0.013\right) ;(4)$ an increase in coral rubble from 1995 to $2011\left(F_{2,12}=2.37, \mathrm{p}=0.032\right)$; and (5) an increase in the cover of Pavona in 2005 followed by its virtual disappearance in $2011\left(F_{3,16}=\right.$ 5.77, $\mathrm{p}=0.007$ ) (Fig. 5).

Offshore, total coral cover declined markedly from 1985 to 1995 (Fig. 2). Although cover increased from 1995 to 2005, it dropped again from 2005 to 2011. Statistically significant changes in the midshore zone included: (1) a massive reduction in Acropora from a) Branching inshore

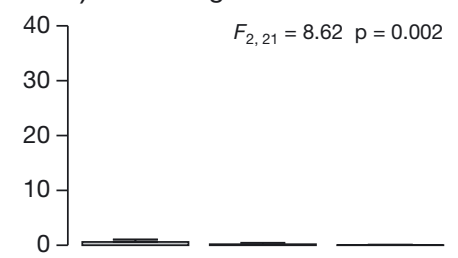

d) Encrusting inshore
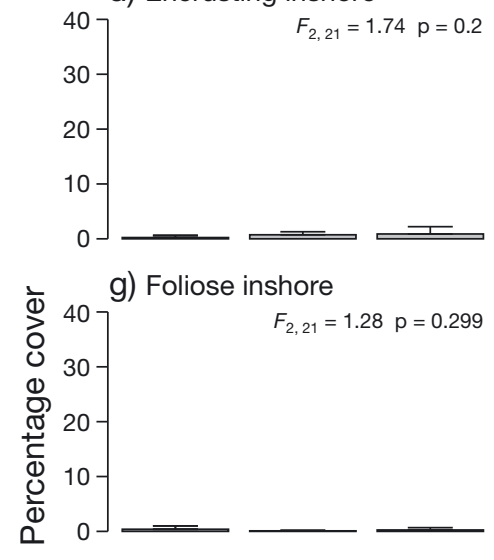

j) Massive inshore

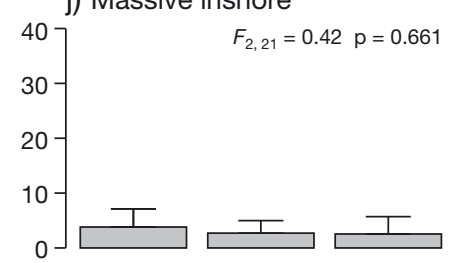

m) Submassive inshore

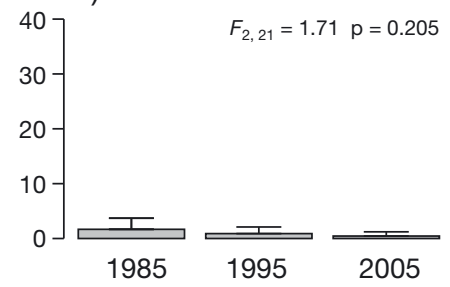

b) Branching midshore

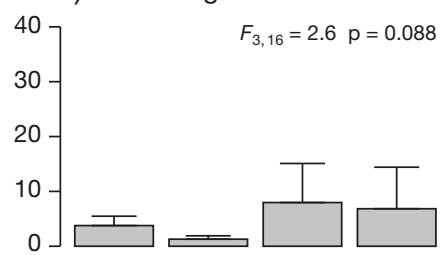

e) Encrusting midshore

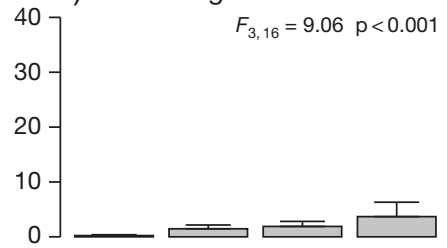

h) Foliose midshore

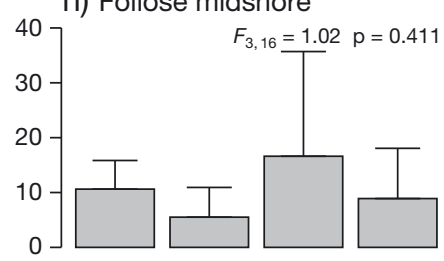

k) Massive midshore

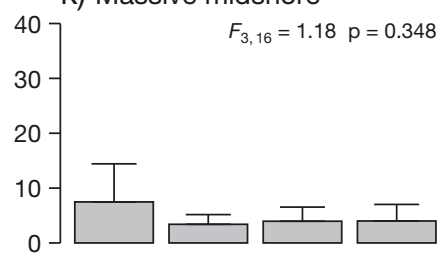

n) Submassive midshore

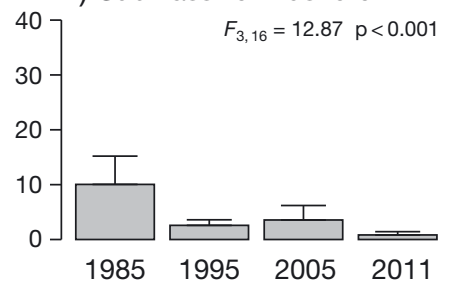

c) Branching offshore
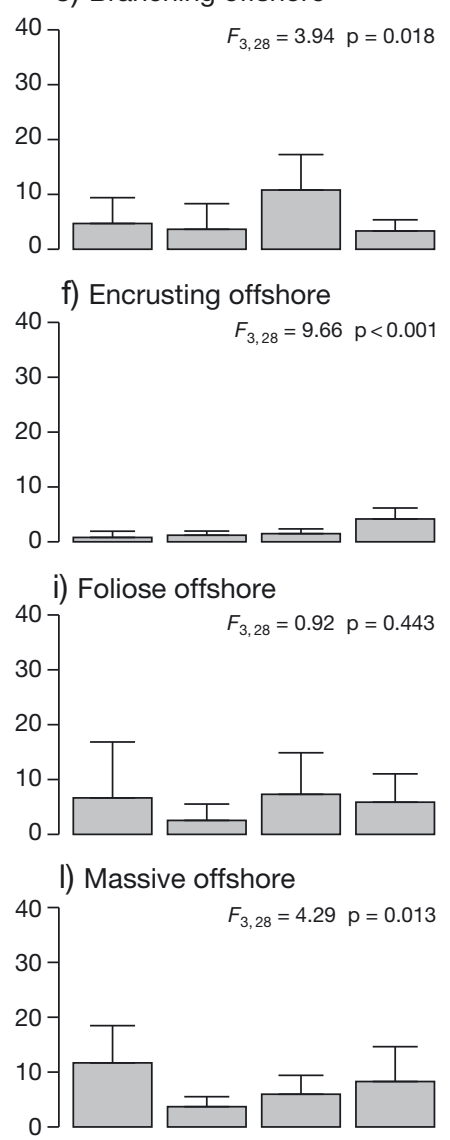

o) Submassive offshore

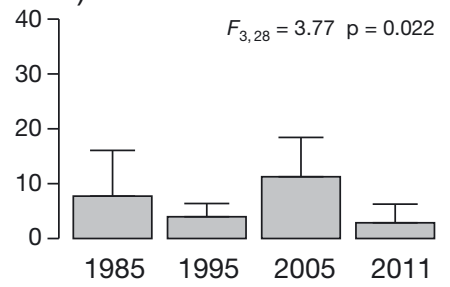

Fig. 3. Mean total coral cover (+1 SD) of branching non-Acropora corals in (a) inshore, (b) midshore and (c) offshore reefs, encrusting corals in (d) inshore, (e) midshore and (f) offshore reefs, foliose corals in ( $\mathrm{g}$ ) inshore, (h) midshore and (i) offshore reefs, massive corals in (j) inshore, (k) midshore and (l) offshore reefs and submassive corals in (m) inshore, (n) midshore and (o) offshore reefs. Results of statistical analyses are given in each panel 
1985 to 1995 followed by an increase in $2005\left(F_{3,28}=\right.$ 5.33, $\mathrm{p}=0.005)$; (2) a marked increase in branching $\left(F_{3,28}=3.94, \mathrm{p}=0.018\right) ;(3)$ submassive $\left(F_{3,28}=3.77\right.$, $\mathrm{p}=0.022)$ coral from 1995 to 2005 followed by drops in cover in 2011; (4) an increase in encrusting coral $\left(F_{3,28}=9.66, \mathrm{p}<0.001\right)$; $(5)$ a reduction in massive coral from 1985 to 1995 followed by a subsequent increase in cover $\left(F_{3,28}=4.29, \mathrm{p}=0.013\right)$ (Fig. 3); (6) a reduction in dead coral from 1995 to 2005 followed by an increase in $2011\left(F_{2,21}=27.22\right.$, $\mathrm{p}<0.001)$; (7) a reduction in algae from 1995 to 2011 $\left(F_{2,21}=6.09, \mathrm{p}=0.008\right) ;(8)$ an increase in coral rubble from 1995 to $2011\left(F_{2,21}=25.34, \mathrm{p}<0.001\right)$ (Fig. 4); (9) a reduction in the cover of Porites from 1985 to 1995 followed by an increase in cover in 2005 and modest drop in $2011\left(F_{3,28}=4.61, \mathrm{p}==0.010\right)$; and (10) a reduction in the cover of Seriatopora from 1985 to 1995 followed by an increase in 2005 and another reduction in cover in $2011\left(F_{3,28}=8.11, \mathrm{p}<0.001\right)$ (Fig. 5).

\section{DISCUSSION}

A number of recent publications (Williams et al. 2000, Cleary et al. 2006, 2008, de Voogd \& Cleary 2008, Renema 2008, Farhan \& Lim 2012, Madduppa et al. 2012) have studied the spatial distribution of

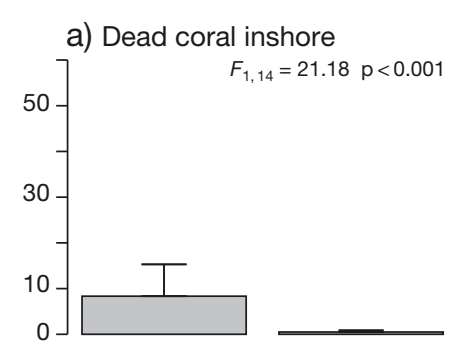

d) Algae inshore

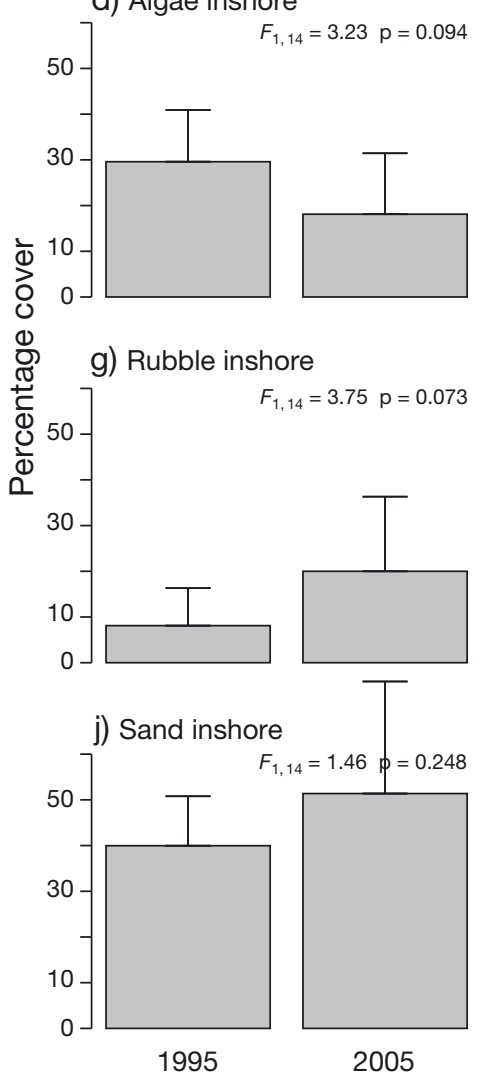

b) Dead coral midshore

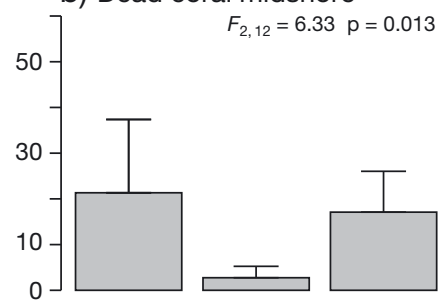

e) Algae midshore

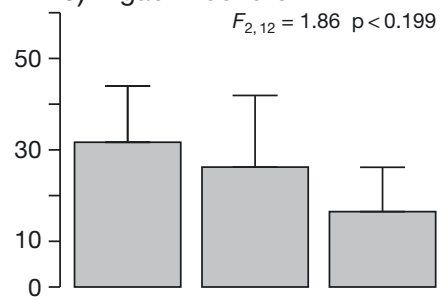

h) Rubble midshore

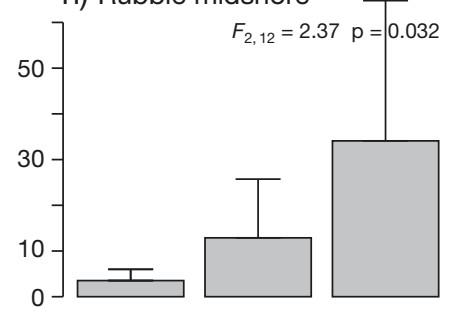

k) Sand midshore

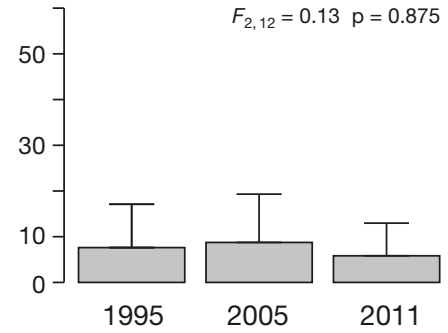

C) Dead coral offshore

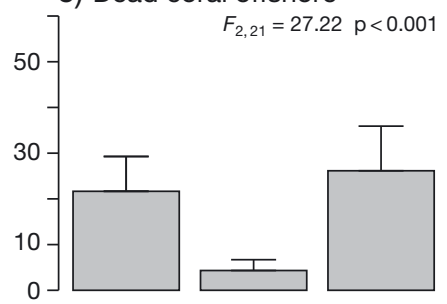

f) Algae offshore

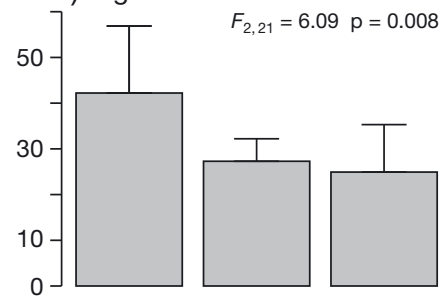

i) Rubble offshore

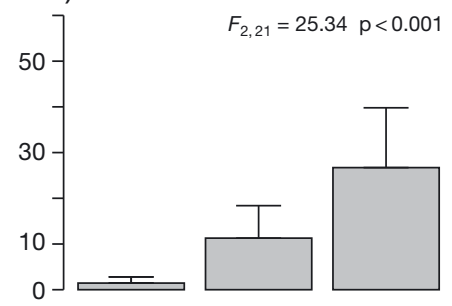

I) Sand offshore

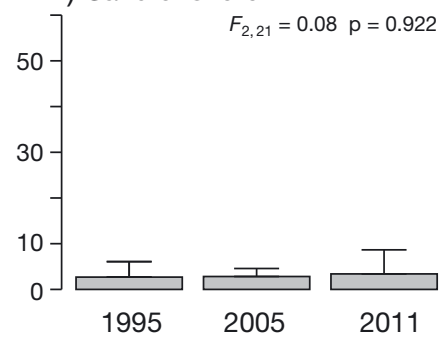

Fig. 4. Mean total coral cover (+1 SD) of dead coral in (a) inshore, (b) midshore and (c) offshore reefs, algae in (d) inshore, (e) midshore and (f) offshore reefs, rubble in $(\mathrm{g})$ inshore, $(\mathrm{h})$ midshore and (i) offshore reefs, and sand in (j) inshore, (k) midshore and (l) offshore reefs. Results of statistical analyses are given in each panel 
various taxa and environmental conditions in JBTI. These studies noted marked in-to-offshore gradients in agrochemicals, heavy metal pollution, nutrient inputs, sediment transport, water transparency and coral composition. The environmental degradation of the inshore reefs has been ongoing for decades and includes physical disturbances in addition to chemical pollution. Four islands, all inshore, have completely disappeared below the waves due to the removal of coral for roads, houses and other infrastructure in combination with blast fishing (Tomascik et al. 1997, Farhan \& Lim 2012). The inshore reefs of Jakarta Bay have been, furthermore, subjected to much higher levels of heavy metals and nutrients than mid- to offshore reefs (Williams et al. 2000, Hosono et al. 2011, Farhan \& Lim 2012, Rinawati et al. 2012). The inshore environment has also become increasingly eutrophic with time (Tomascik et al. 1993).

Today, the inshore reefs of Jakarta Bay are very different than in the historical past. In 1929, inshore reefs were thriving. Umbgrove (1939) recorded a diverse coral assemblage around the island of Nyamuk (Fig. 1) alone and described the characteristic Montipora digitata and $M$. foliosa assemblages and large

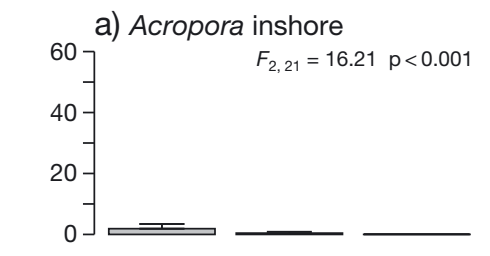

d) Porites inshore

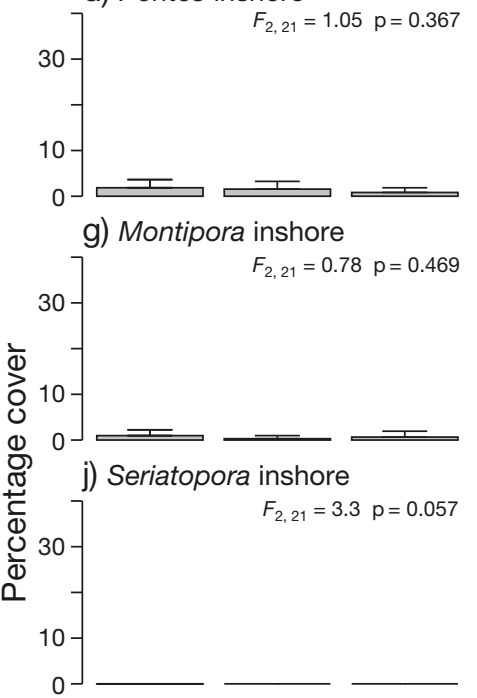

m) Echinopora inshore

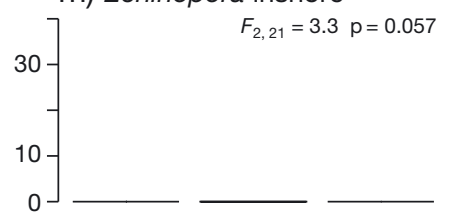

p) Pavona inshore

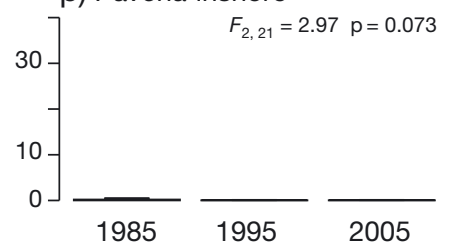

b) Acropora midshore

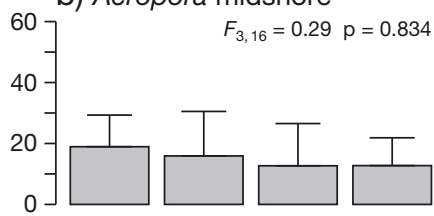

e) Porites midshore

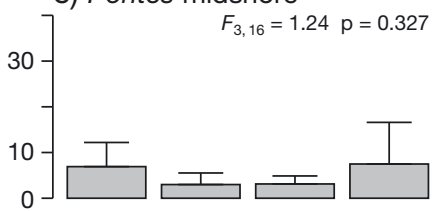

h) Montipora midshore

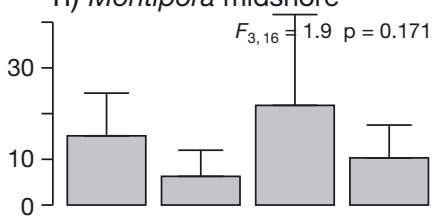

k) Seriatopora midshore

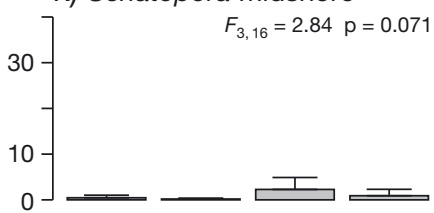

n) Echinopora midshore

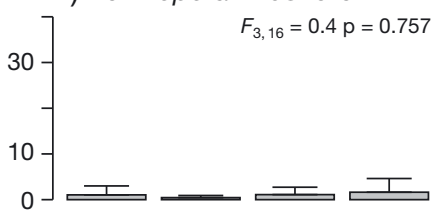

q) Pavona midshore

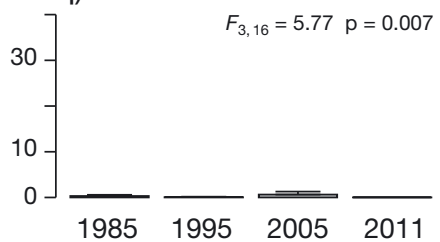

c) Acropora offshore

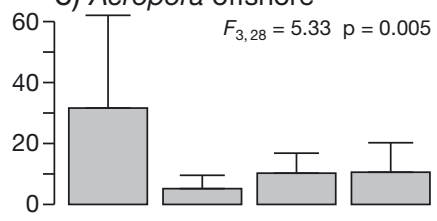

f) Porites offshore

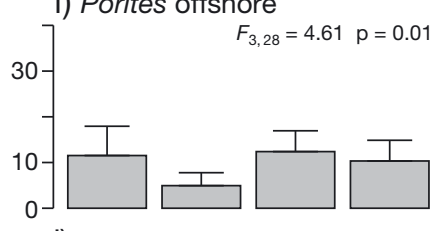

i) Montipora offshore

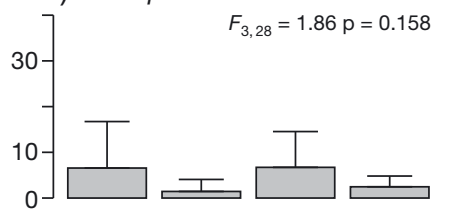

I) Seriatopora offshore

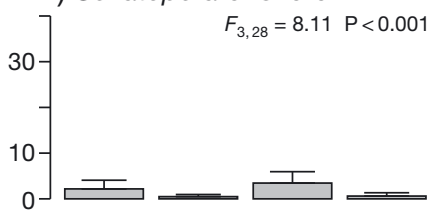

o) Echinopora offshore

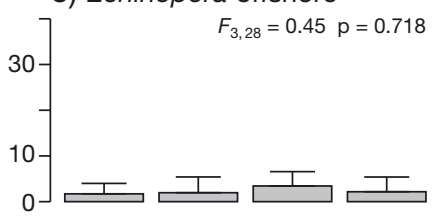

r) Pavona offshore

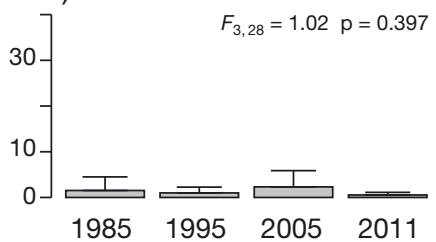

Fig. 5. Mean total coral cover (+1 SD) of Acropora in (a) inshore, (b) midshore and (c) offshore reefs; Porites in (d) inshore, (e) midshore and (f) offshore reefs; Montipora in (g) inshore, (h) midshore and (i) offshore reefs; Seriatopora in (j) inshore, (k) midshore and (l) offshore reefs; Echinopora in (m) inshore, (n) midshore and (o) offshore reefs; and Pavona in (p) inshore, (q) midshore and (r) offshore reefs. Results of statistical analyses are given in each panel 
Acropora aspera moat. These have completely disappeared. In 2005, we recorded 3.8\% coral cover at Nyamuk; $89 \%$ of the reef consisted of rubble, sand and algae. In 1985, there was still a small amount of Acropora present $(1.8 \%)$. This, however, declined to only $0.3 \%$ in 1995 and had disappeared to $0 \%$ by 2005 .

The inshore coral reefs of JBTI will probably remain in a severely degraded state for the foreseeable future. Tomascik et al. (1997) previously reported relatively little change in water transparency of the most inshore reefs (e.g. those of Onrust and Kelor) from 1929 to 1993 but a marked drop in the water transparency of more offshore reefs. Our water transparency data confirm this but show an additional reduction in water transparency inshore from 1995 to 2005, suggesting a further decline in the inshore environment. The proximity to Jakarta must thus be seen as the major cause of the present state of the inshore reef environment.

Despite, or rather because of, the dilapidated state of the inshore reefs, there was relatively little pronounced absolute change in coral cover or abundance when compared with mid- and offshore reefs. The recent history of the inshore reefs appears to be one of slow degradation, including the loss of the already low Acropora and non-Acropora branching coral cover. The degradation of the inshore reefs had already begun well before the onset of the present study in 1985 (Hosono et al. 2011, Farhan \& Lim 2012).

Midshore, the degree of loss in coral cover was less pronounced than offshore. The midshore zone also contained sites with markedly different trajectories in coral cover across time. For example, there was a massive loss of coral at the Bokor site but maintenance of high coral cover at other midshore sites. Importantly, Bokor is the most inshore of the midshore sites and its loss of coral cover may reflect a gradual spreading of adverse 'inshore' conditions. Midshore sites were, furthermore, characterised by increases in encrusting coral cover and coral rubble and the loss of submassive coral cover.

During the time period of this study, offshore reefs have been subject to much greater shifts in cover and abundance than in- or midshore reefs. Following the dramatic loss of Acropora offshore from 1985 to 1995, Acropora cover has since increased to $>10 \%$ in 2011. The total coral cover loss we observed in JBTI also reflects that recorded by Guest et al. (2012). In the study of Guest et al. (2012) and the present study, there was little change in the cover of Acropora corals following the severe 2010 bleaching event, but a marked loss of non-Acropora branching and submassive species.
The 2010 beaching event is noteworthy. During this event, there was a very strong thermal anomaly that led to severe bleaching throughout Indonesia, the Indo-Pacific in general and the Caribbean (Hoeksema \& Matthews 2011, Krishnan et al. 2011, del Mónaco et al. 2012, Guest et al. 2012, van Woesik et al. 2012). At one locality in Indonesia (Pulau Weh, Sumatra) that was unaffected by the 1997-98 El Niño Southern Oscillation (ENSO) event, coral bleaching led to the demise of $>90 \%$ of Acropora colonies (Guest et al. 2012). However, at localities in Singapore, Malaysia and JBTI that were heavily affected by the 1997-98 ENSO event, Acropora was largely unaffected (UNESCO 2000, Guest et al. 2012). In contrast, massive corals experienced bleaching, but total colony mortality was limited. Branching Porites were severely affected in the Singapore and Malaysia localities sampled, with colony mortality ranging from 46 to $60 \%$ (Guest et al. 2012). Guest et al. (2012) suggested that the marked lack of bleaching Acropora in previously affected areas was due to the selective removal of susceptible individuals during previous bleaching events followed by successful recruitment of more thermally tolerant individuals.

Total coral cover offshore more than doubled from 1995 to 2005; as previously noted, this increase was mainly due to increases in the cover of non-Acropora branching as well as submassive species. However, both of these groups later declined in cover from 2005 to 2011 . There was also a pronounced rise in the cover of dead coral from 2005 to 2011. Given the amount of live and dead coral (>60\%), our data suggest that offshore coral cover was closely approaching pre-disturbance levels (i.e. 1985 levels: 66.7\%) up to 2010, when severe bleaching during the 2010 ENSO event proved an important setback for coral recovery in JBTI.

Although coral cover on offshore reefs has improved substantially from 1995 to 2011, coral cover still remains lower than in 1985, albeit higher than in many other Indo-Pacific reefs and much of the Great Barrier Reef (Bruno \& Selig 2007). The offshore reefs should, however, not be seen as an isolated case but rather part of the global phenomenon of the rapid degradation of previously thriving coral reefs from the 1980s onwards. Virtually the same process has been described in the Caribbean and Great Barrier Reef, both thousands of kilometres away (Connell 1997, Done et al. 2007). Coral reefs across the globe have declined dramatically since the 1980 s due to unsustainable fishing, pollution, eutrophication, disease, bleaching, algal overgrowth and general environmental degradation (Bellwood et al. 2004, 
Bruno \& Selig 2007, Hughes et al. 2010, De'ath et al. 2012). The substantial increase in coral rubble in JBTI is striking. In 2011, coral rubble covered $20.0 \%$ of inshore, $37.1 \%$ of midshore and $26.7 \%$ of offshore reefs. Importantly, extensive fields of coral rubble tend to shift in currents thereby hampering colonisation by coral recruits. This can severely inhibit reef recovery for extended periods of time (Fox \& Caldwell 2006).

Despite the plethora of stressors affecting JBTI, the reefs have shown a propensity to recover. The exception is the inshore Jakarta Bay area, which has been so severely impacted that coral-dominated reefs have now effectively disappeared. The substantial increase in Acropora coral cover from 1995 onwards following the dramatic loss of cover between 1985 and 1995 is important. This recovery has coincided with an overall improvement of the marine environment. For example, Hosono et al. (2011) noted that anthropogenic metal accumulation in the sediment of Jakarta Bay increased greatly from the 1970s until the late 1990 s, a period coinciding with the marked decline in coral cover in our study. From the late 1990s until 2006, however, accumulation rates were either constant or declining. Hosono et al. (2011) attributed this amelioration to stricter environmental regulations starting in the late 1990s. The reduction in metal contamination found by Hosono et al. (2011) fits well with our data, which showed an increase in coral cover and water transparency from 1995 to 2005. The increase of Acropora cover in our study, however, contrasts with trajectories in the Caribbean (Cramer et al. 2012) and the Great Barrier Reef (Done et al. 2010, Roff et al. 2013), where Acropora has proved to be one of the most vulnerable corals and has largely disappeared from nearshore areas.

Acknowledgements. We received support from UNESCO and the Research Centre for Oceanography, Indonesian Institute of Sciences (PPO-LIPI, Jakarta) and in particular A. Budiyanto, Giyanto and Suharsono. The research permit (6a/TKPIPA/FRP/SM/VI/2011) was issued by the Indonesian State Ministry of Research and Technology (RISTEK). We thank A. Duine and E. Dondorp for their help in the field. Research was funded by the Portuguese Foundation for Science and Technology, FCT, project LESS CORAL, PTDC/ AAC-AMB/115304/2009.

\section{LITERATURE CITED}

Bellwood DR, Hughes TP, Folke C, Nyström M (2004) Confronting the coral reef crisis. Nature 429:827-833

$>$ Bruno JF, Selig ER (2007) Regional decline of coral cover in the Indo-Pacific: timing, extent, and subregional comparisons. PLoS ONE 2:e711
Carpenter KE, Arbar M, Aeby G, Aronson RB and others (2008) One-third of reef-building corals face elevated extinction risk from climate change and local impacts. Science 321:560-563

> Cleary DFR, Suharsono, Hoeksema BW (2006) Coral diversity across a disturbance gradient in the Pulau Seribu reef complex off Jakarta, Indonesia. Biodivers Conserv 15:3653-3674

> Cleary DFR, DeVantier L, Giyanto, Vail L and others (2008) Relating variation in species composition to environmental variables: a multi-taxon study in an Indonesian coral reef complex. Aquat Sci 70:419-431

Connell J (1997) Disturbance and recovery of coral assemblages. Coral Reefs 16(Suppl):101-113

> Cramer KL, Jackson JB, Angioletti CV, Leonard-Pingel J, Guilderson TP (2012) Anthropogenic mortality on coral reefs in Caribbean Panama predates coral disease and bleaching. Ecol Lett 15:561-567

de Voogd NJ, Cleary DFR (2008) An analysis of sponge diversity and distribution at three taxonomic levels in the Thousand Islands/Jakarta Bay reef complex, West-Java, Indonesia. Mar Ecol 29:205-215

> De'ath G, Fabricius KE, Sweatman H, Puotinen M (2012) The 27-year decline of coral cover on the Great Barrier Reef and its causes. Proc Natl Acad Sci USA 109: 17995-17999

del Mónaco C, Haiek G, Narciso S, Galindo M (2012) Massive bleaching of coral reefs induced by the 2010 ENSO, Puerto Cabello, Venezuela. Rev Biol Trop 60:527-538

Demographia (2013) World urban areas (world agglomerations), 9th annual edn, March 2013. Demographia, Belleville, IL. www.demographia.com/db-worldua.pdf

DeVantier L Suharsono, Budiyanto A, Tuti Y, Imanto P, Ledesma R (1998) Status of coral communities of Pulau Seribu, 1985-1995. In: Soemodijhardjo S (ed) Contending with global change. Proc coral reef evaluation workshop Pulau Seribu, Jakarta, Indonesia. September 1995. UNESCO, Jakarta, p 11-20

Done T, Turak E, Wakeford M, DeVantier LM, McDonald A, Fisk D (2007) Decadal changes in turbid-water coral communities at Pandora Reef: loss of resilience or too soon to tell? Coral Reefs 26:789-805

> Done TJ, DeVantier LM, Turak E, Fisk DA, Wakeford M, van Woesik R (2010) Coral growth on three reefs: development of recovery benchmarks using a space for time approach. Coral Reefs 29:815-833

English SC, Wilkinson CR, Baker V (1997) Survey manual for tropical marine resources, 2nd edn. ASEAN-Australia marine science project: living coastal resources. Australian Institute of Marine Science, Townsville

> Farhan AR, Lim S (2012) Vulnerability assessment of ecological conditions in Seribu Islands, Indonesia. Ocean Coast Manag 65:1-14

Fox HE, Caldwell RL (2006) Recovery from blast fishing on coral reefs: a tale of two scales. Ecol Appl 16:1631-1635

> Guest JR, Baird AH, Maynard JA, Muttaqin E and others (2012) Contrasting patterns of coral bleaching susceptibility in 2010 suggest an adaptive response to thermal stress. PLoS ONE 7:e33353

> Hoeksema BW, Matthews JL (2011) Contrasting bleaching patterns in mushroom coral assemblages at Koh Tao, Gulf of Thailand. Coral Reefs 30:95

> Hosono T, Su CC, Delinom R, Umezawa Y, Toyota T, Kaneko S (2011) Decline in heavy metal contamination in marine sediments in Jakarta Bay, Indonesia due to 
increasing environmental regulations. Estuar Coast Shelf Sci 92:297-306

Hughes TP, Graham NAJ, Jackson JBC, Mumby PJ, Steneck RS (2010) Rising to the challenge of sustaining coral reef resilience. Trends Ecol Evol 25:633-642

Jackson JBC, Kirby MX, Berger WH, Bjorndal KA and others (2001) Historical overfishing and the recent collapse of coastal ecosystems. Science 293:629-637

Krishnan P, Roy SD, George G, Srivastava RC and others (2011) Elevated sea surface temperature during May 2010 induces mass bleaching of corals in the Andaman. Curr Sci 100:111-117

Kuijper MWM (2003) Marine and coastal environmental awareness building within the context of UNESCO's activities in Asia and the Pacific. Mar Pollut Bull 47: 265-272

Madduppa H, Ferse SA, Aktani U, Palm H (2012) Seasonal trends and fish-habitat associations around Pari Island, Indonesia: setting a baseline for environmental monitoring. Environ Biol Fishes 95:383-398

Pandolfi JM, Bradbury RH, Sala E, Hughes TP and others (2003) Global trajectories of the long-term decline of coral reef ecosystems. Science 301:955-958

R Core Team (2013) R: a language and environment for statistical computing. Vienna. www.R-project.org

Rachello-Dolmen PG, Cleary DFR (2007) Coral species, traits and environmental conditions in Jakarta Bay/Pulau Seribu reef complex. Estuar Coast Shelf Sci 73:816-826

Rees JG, Setiapermana D, Sharp VA, Weeks JM, Williams TM (1999) Evaluation of the impacts of land-based contaminants on the benthic faunas of Jakarta Bay, Indonesia. Oceanol Acta 22:627-640

Renema W (2008) Habitat selective factors influencing the distribution of large benthic foraminifera assemblages over the Kepulauan Seribu. Mar Micropaleontol 68: 286-298

Rinawati, Koike $\mathrm{T}$, Koike $\mathrm{H}$, Kurumisawa $\mathrm{R}$ and others (2012) Distribution, source identification, and historical trends of organic micropollutants in coastal sediment in Jakarta Bay, Indonesia. J Hazard Mater 217-218: 208-216

Roff G, Clark TR, Reymond CE, Zhao JX and others (2013) Palaeoecological evidence of a historical collapse of corals at Pelorus Island, inshore Great Barrier Reef, following European settlement. Proc Biol Sci 280:20122100

Solan M, Cardinale BJ, Downing AL, Engelhardt KAM, Ruesink JL, Srivastava DS (2004) Extinction and ecosystem function in the marine benthos. Science 306:1177-1180

Sweatman HPA, Delean S, Syms C (2011) Assessing loss of coral cover on Australia's Great Barrier Reef over two decades with implications for longer-term trends. Coral Reefs 30:521-531

Tomascik T, Suharsono, Mah AJ (1993) Case histories: a historical perspective of the natural and anthropogenic impacts in the Indonesian archipelago with a focus on

Editorial responsibility: Richard Osman, Edgewater, Maryland, USA
Kepulauan Seribu, Java Sea. In: Ginsburg R (ed) Proc colloquium on global aspects of coral reefs: health, hazards and history. Rosenstiel School of Marine and Atmospheric Science, University of Miami, Miami, FL

Tomascik T, Mah AJ, Nontji A, Moosa MK (1997) The ecology of the Indonesian Seas, Vol 2. Periplus Editions, Singapore

Umbgrove JHF (1939) Madreporaria from the bay of Batavia. Zool Meded 22:1-64

UNESCO (2000) Reducing megacity impacts on the coastal environment - alternative livelihoods and waste management in Jakarta and the Seribu Islands. Coastal Region and Small Island Papers 6. UNESCO, Paris

van Woesik R, Houk P, Isechal AL, Idechong JW, Victor S, Golbuu Y (2012) Climate-change refugia in the sheltered bays of Palau: analogs of future reefs. Ecol Evol 2: 2474-2484

Williams TM, Rees JG, Setiapermana D (2000) Metals and trace organic compounds in sediments and waters of Jakarta Bay and the Pulau Seribu Complex, Indonesia. Mar Pollut Bull 40:277-285

\section{Appendix.}

Table A1. Number of transects sampled at each sampling site during each sampling event. All sites were exposed and sampled from the northwest side. NA: no transects were sampled

\begin{tabular}{|c|c|c|c|c|c|c|}
\hline Site & Island & Zone & 1985 & 1995 & 2005 & 2011 \\
\hline AyB & Ayer Besar & 1 & 2 & 11 & 6 & NA \\
\hline Bid & Bidadari & 1 & 2 & 12 & 6 & NA \\
\hline $\mathrm{DaK}$ & Damar Kecil & 1 & 2 & 11 & 6 & NA \\
\hline Kel & Kelor & 1 & 2 & 12 & 6 & NA \\
\hline NyB & Nyamuk & 1 & 2 & 12 & 6 & NA \\
\hline Onr & Ounrust & 1 & 2 & 12 & 6 & NA \\
\hline $\mathrm{UbB}$ & Ubi & 1 & 2 & 12 & 6 & NA \\
\hline UnJ & Untung Jawa & 1 & 2 & 12 & 6 & NA \\
\hline Bok & Bokor & 2 & 4 & 12 & 6 & 2 \\
\hline Dap & Dapur & 2 & 2 & 12 & 6 & 1 \\
\hline $\mathrm{LaB}$ & Lancang Besar & 2 & 2 & 12 & 6 & 2 \\
\hline TdK & Tidung Kecil & 2 & 2 & 12 & 6 & 1 \\
\hline TkU & Tikus Utara & 2 & 2 & 12 & 6 & 2 \\
\hline Air & Air & 3 & 2 & 12 & 6 & 2 \\
\hline Bel & Belanda & 3 & 2 & 12 & 6 & 2 \\
\hline $\mathrm{HaB}$ & Hantu Besar & 3 & 2 & 12 & 6 & 2 \\
\hline KoK & Kotok Kecill & 3 & 1 & 12 & 6 & 2 \\
\hline Кра & Kelapa & 3 & 2 & 12 & 6 & 2 \\
\hline Pan & Panjang kecil & 3 & 2 & 12 & 6 & 2 \\
\hline Put & Putri & 3 & 2 & 12 & 6 & 2 \\
\hline $\mathrm{SeB}$ & Sepa & 3 & 2 & 12 & 6 & 2 \\
\hline
\end{tabular}

Submitted: March 4, 2013; Accepted: December 2, 2013 Proofs received from author(s): February 28, 2014 